\title{
Pengaruh Total Persediaan, Total Aktiva dan Total Modal terhadap Laba Bersih pada Sub Sektor Properti dan Real Estate yang Terdaftar di Bursa Efek Indonesia (BEI) Periode 2012-2016
}

\author{
Hana Tamara Putri \\ Fakultas Ekonomi, Universitas Batanghari Jambi
}

\begin{abstract}
The purpose of this research is to know the influence of the total inventory, total assets and total working capital simultaneosly and partially to net profit on subsector of property and real estates on period 2012-2016. This research is a desciptive quantitative research and analysis tool used in this research are multiple linear regression is useful to see the direction of the relationship between the variable-variable bound against free. For the purpose of answering the number one used statistical test i.e test $F$ and to answer the purpose number 2 used statistical test i.e test $t$. The correlation coefficient to know how the relationship between variables and coefficients of determination of useful to see the magnitude of the influence of the variable bound against free. Result SPSS 20 get a multiple linear regression equation is $\log Y=4-0,103+0,156 X_{1}+0,748$ $X_{2}-0,049 X_{3}+e$. The corellation is 0,774 , meaning that is a close relationship between the variable total inventory $\left(X_{1}\right)$, total assets $\left(X_{2}\right)$ and working capital $\left(X_{3}\right)$ of net profit $(Y)$ on sub sector of property and real estate on period 20122016. From the result of the obtained values SPSS (coefficient) $r^{2}$ this figure amounted 59,9\% states that the variable total inventory, total assets and working capital of the able to explain the variabel net profit by 59,9\% and the reaining $40,1 \%$ is explained by other factors which is not included in the research model. Simultaneously the total inventory, total assets and working capital of a significant effect on net profit on sub sector of property and real estate on period 2012-016 and partially total inventory has no influence on net profit and working capital total asset has an influence on net profit on sub sector of property and real estate on period 2012-2016
\end{abstract}

Keyword: total inventory, total assets, working capital, net profit

\section{PENDAHULUAN}

Proses penjualan pada perusahaan properti tidak lepas dari pengaruh persediaan yang dimiliki oleh perusahaan. Persediaan merupakan pos aktiva lancar seluruh perusahaan yang nilainya cukup besar sehingga pos persediaan memiliki peran penting bagi perusahaan. Persediaan merupakan unsur aktif dalam kegiatan operasional perusahaan, karena jumlah persediaan dalam perusahaan selalu berubah karena adanya pengurangan untuk proses produksi yang akan dijual kepada konsumen. Dengan adanya manajemen persediaan yang baik dalam perusahaan, perusahaan dapat dengan cepat mengubah dana yang tersimpan dalam bentuk persediaan menjadi kas atau piutang melalui penjualan yang nantinya akan menjadi laba perusahaan (Adisetiawan dan Surono, 2016)

Manajemen keuangan memperkirakan aspek lain yang dapat meningkatkan laba perusahaan, aspek tersebut dinilai dari tingkat pengembalian investasi pada aktiva yang digunakan di dalam proses produksi, berapa besar

Pengaruh Total Persediaan, Total Aktiva dan Total Modal terhadap Laba Bersih pada Sub Sektor Properti dan Real Estate yang Terdaftar di Bursa Efek Indonesia 
tingkat pengembalian yang diterima dari dana yang ditanamkan dalam aktiva lancar dan aktiva tetap. Aktiva memiliki tiga karakteristik utama yaitu memiliki manfaat ekonomi di masa mendatang, dikuasai oleh suatu unit usaha dan hasil dari transaksi masa lalu (Adisetiawan dan Surono, 2016)

Modal merupakan investasi perusahaan jangka pendek yang dimiliki oleh perusahaan, mengingat pentingnya modal di dalam perusahaan, manajer keuangan juga dituntut harus dapat merencanakan dengan baik besarnya jumlah modal yang tepat dan sesuai dengan kebutuhan perusahaan, karena jika perusahaan kelebihan modal akan menyebabkan banyak dana yang menganggur, sehingga hal ini dapat menyebabkan perusahaan mengalami rugi akibat penggunaan dana yang tidak efektif dan dapat memperkecil profitabilitas. Sedangkan apabila terjadi kekurangan modal, maka akan menghambat kegiatan operasional perusahaan.

Bisnis properti saat ini memberikan peluang dan kesempatan yang cukup terbuka untuk berkembang. Beberapa faktor yang mempengaruhinya antara lain pengadaan rumah selalu kurang dibanding kebutuhan rumah masyarakat, tingkat suku bunga KPR relatif rendah dan cenderung tidak stabil. Terbukanya peluang tersebut, tentunya menjadi suatu kesempatan untuk menarik para investor asing maupun domestik untuk berinvestasi. Fenomena yang berkembang pada saat ini menggambarkan bahwa sektor properti dan real estate merupakan sektor bisnis yang cukup berkembang. Hal ini terbukti dengan adanya krisis yang menjadi beban benua Eropa dan Amerika yang tidak berimbas pada perkembangan bisnis properti dan real estate di Indonesia (Adisetiawan dan Atikah, 2018).

Fenomena pada bisnis properti Indonesia sekarang adalah pembangunan superblok. Meski harus mengeluarkan investasi lebih besar dibandingkan dengan membangun perumahan biasa, pengembangan semakin agresif mengembangkan kawasan superblok. Langkah pengembangan itu karena kawasan terpadu memang memiliki daya tarik lebih tinggi dibandingkan dengan perumahan biasa. Pertumbuhan sektor properti akan menjadi stimulan bagi perekonomian nasional. Karena pertumbuhan sektor properti terkait erat dengan meningkatnya pendapatan masyarakat. Jika kondisi sektor properti mengalami keterpurukan maka dikhawatirkan pasar properti akan mengalami kerugian besar dan perekonomian Indonesia akan jatuh, dan sulit sekali untuk membangun kembali sektor properti yang lebih stabil (Adisetiawan dan Atikah, 2018).

Tujuan dari penelitian ini adalah mengetahui pengaruh total persediaan, total aktiva dan total modal secara simultan dan parsial berpengaruh terhadap laba bersih pada sub sektor properti and real estate yang terdaftar di Bursa Efek Indonesia (BEI) periode 2012-2016.

\section{Tinjauan Pustaka}

Menurut Ristono (2009: 1) persediaan adalah barang-barang yang disimpan untuk digunakan atau dijual pada masa atau periode yang akan datang. Persediaan terdiri dari persediaan bahan baku, persediaan bahan setengah jadi dan persediaan barang jadi. Skousen (2008: 360) mendefinisikan bahwa persediaan adalah nama yang diberikan untuk barang-barang baik yang dibuat atau dibeli untuk dijual kembali dalam bisnis yang normal. Berdasarkan definisi diatas dapat ditarik kesimpulan bahwa persediaan merupakan sejumlah barang yang disediakan perusahaan dan bahan-bahan yang terdapat di perusahaan untuk proses 
produksi, serta barang-barang atau produk jadi yang disebabkan untuk memenuhi permintaan dari konsumen atau langganan setiap waktu.

Menurut Kasmir (2008: 39), aktiva adalah harta atau kekayaan yang dimiliki oleh perusahaan, baik pada saat tertentu maupun periode tertentu. Berikut ini pembagian dari aktiva:

1. Aktiva Lancar

Menurut Munawir (2004:14), aktiva lancar adalah uang kas dan aktiva lainnya yang dapat diharapkan, dapat dicairkan atau ditukar menjadi uang tunai, dijual atau dikonsumsi dalam periode berikutnya (paling lama satu tahun atau dalam perputaran kegiatan perusahaan yang normal).

2. Aktiva Tetap

Menurut Mulyadi (2014: 179) aktiva tetap adalah kekayaan perusahaan yang memiliki wujud, mempunyai manfaat ekonomis lebih dari satu tahun, dan diperoleh untuk melaksanakan kegiatan perusahaan bukan untuk dijual kembali.

Menurut Mulyadi (2014: 179) aktiva tetap dalam perusahaan manufaktur umumnya digolongkan menjadi: Tanah dan perbaikan tanah (land and land improvement), Gedung dan perbaikan gedung (building and building improvement), Mesin dan ekuipmen pabrik, Mebel, dan Kendaraan.

\section{Konsep Total Modal}

Menurut Kasmir (2012:210) total modal adalah sebagai modal yang digunakan untuk membiayai operasional perusahaan sehari-hari, terutama memiliki jangka pendek. Modal juga di artikan seluruh aktiva lancaryang dimiliki suatu perusahaan atau setelah aktiva lancar dikurangi dengan hutang lancar. Menurut Basri (2008:35) total modal adalah kekayaan atau aktiva yang di perlukan oleh perusahaan untuk menyelenggarakan kegiatan sehari-hari yang selalu berputar dalam periode tertentu". Total modal atau working capital, sering pula disebut gross working capital atau modal kerja kotor, didefinisikan sebagai item-item pada aktiva lancar, yakni: Kas (cash), sedangkan modal kerja bersih atau net working capital adalah aktiva lancar setelah dikurangi dengan hutang lancar", mengenai pengertian modal kerja ini, Riyanto (2010:57-58) mengemukakan adanya beberapa konsep yaitu konsep kuantitatif,kualitatif dan fugsional, yang juga di ungkapkan oleh Kasmir (2011:211) dan Basri (2008:3335)

\section{Hubungan Antar Variabel \\ Total Persediaan Terhadap Laba Bersih}

Persediaan dalam perusahaan menunjukkan kinerja perusahaan dalam aktivitas operasionalnya. Semakin tinggi tingkat persediaan, kemungkinan semakin besar perusahaan akan memperoleh keuntungan. Begitu pula sebaliknya, jika tingkat persediannya rendah maka kemungkinan semakin kecil perusahaan akan memperoleh keuntungan Menurut Raharja Putra (2009: 67). Munawir (2004: 57) menyatakan bahwa semakin tinggi tingkat persediaan akan memperkecil risiko terhadap kerugian yang disebabkan karena penurunan harga atau karena perubahan selera konsumen, disamping itu akan menghemat ongkos penyimpanan dan pemeliharaan terhadap persediaan tersebut. 


\section{Total Aktiva Terhadap Laba Bersih}

Beberapa ahli menyatakan adanya hubungan antara total aktiva terhadap laba bersih. Menurut Sartono (2006: 132) hubungan total aktiva terhadap laba bersih yaitu dapat menunjukkan bagaimana efektivitas perusahaan menggunakan keseluruhan aktiva untuk menciptakan penjualan dan pada akhirnya akan menghasilkan laba. Menurut Halim (2007: 78) pengaruh total aktiva terhadap laba bersih adalah semakin cepat tingkat total aktivanya maka laba yang dihasilkan akan semakin meningkat, karena perusahaan sudah dapat memanfaatkan aktiva tersebut untuk meningkatkan penjualan yang berpengaruh terhadap pendapatan. Kenaikan pendapatan dapat mempengaruh laba bersih setiap tahunnya.

\section{Total Modal Terhadap Laba Bersih}

Semakin besar total modal menunjukkan efektifnya pemanfaatan modal yang tersedia dalam meningkatkan profitabilitas perusahaan. Ini berarti bahwa semakin besar total modal maka semakin baik suatu perusahaan dimana persentase modal yang ada mampu menghasilkan jumlah penjualan tertentu sehingga dapat mempengaruhi laba.

\section{Hipotesis}

Hipotesis adalah pernyataan atau dugaan yang bersifat sementara terhadap suatu masalah penelitian dan kebenarannya, Sulistyastuti (2007: 137). Berdasarkan rumusan masalah yang telah disebutkan maka hipotesis dari penelitian ini adalah diduga total persediaan, total aktiva dan total modal secara simultan berpengaruh terhadap laba bersih pada sub sektor properti and real estate periode 2012-2016.

\section{METODE}

Pada penelitian ini metode penelitian yang digunakan adalah metode deskriptif yaitu studi yang bersifat suatu paparan variabel-variabel yang diteliti maupun ketergantungan sub-sub variabel nya. Dalam penelitian ini data yang digunakan adalah jenis data sekunder berupa laporan tahunan sub sektor properti and real estate yang terdaftar di Bursa Efek Indonesia (BEI) yang diambil melalui situs www.idx.co.id.Untuk mendapatkan data yang diperlukan dalam penelitian ini dilakukan dengan cara penelitian kepustakaan (Library Research). Populasi yang digunakan dalam penelitian ini adalah sub sektor properti and real estate yang terdaftar dan telah melakukan pelaporan keuangannya di Bursa Efek Indonesia (BEI) selama periode tahun 2012-2016 sebanyak 49 perusahaan yang listing di BEI.

Tabel 1

Kriteria Sampel Penelitian

\begin{tabular}{llr}
\hline No & \multicolumn{1}{c}{ Kriteria Penarikan Sampel } & \multicolumn{1}{c}{$\begin{array}{c}\text { Jumlah } \\
\text { Perusahaan }\end{array}$} \\
\hline 1 & Perusahaan yang listing periode penelitian 2012-2016 & 49 \\
2 & Perusahaan yang memiliki kelengkapan data terkait & 22 \\
& variabel penelitian & 13 \\
3 & Perusahaan yang mempunyai laba dengan nilai negatif & 9 \\
4 & Sampel Penelitian & \\
\hline
\end{tabular}


Adapun perusahaan tersebut adalah PT. Sentul City Tbk, PT. Bumi Serpong Damai Tbk, PT. Ciputra Development Tbk, PT. Duta Anggada Realty Tbk, PT. Intiland Development Tbk, PT. Duta Pertiwi Tbk, PT. Gowa Makassar Tourism Development Tbk, PT. Lippo Karawaci Tbk dan PT. Lippo Cikarang Tbk. Metode analisis data yang digunakan dalam penelitian ini adalah:

\section{Analisis Regresi Linear Berganda}

Untuk mengetahui apakah rasio keuangan berpengaruh terhadap laba bersih dan seberapa besar pengaruhnya maka digunakan analisis regresi linear berganda, adapun persamaan dari regresi linear berganda dalam penelitian ini adalah sebagai berikut:

$\mathbf{Y}=\mathbf{a}+\mathbf{b}_{1} \mathbf{X}_{1}+\mathbf{b}_{2} \mathbf{X}_{2}+\mathbf{b}_{3} \mathbf{X}_{3}+\mathbf{e}$

Dimana: $\mathrm{Y}=$ Laba Bersih; $\mathrm{X}_{1}=$ Persediaan $\mathrm{X}_{2}=$ Aktiva; $\mathrm{X}_{3}=$ Modal; $\mathrm{a}=$

Konstanta; $\mathrm{b}=$ koefisien regresi; $\mathrm{e}=$ error

\section{Uji Asumsi Klasik}

Sebelum melakukan uji hipotesis maka terlebih dahulu dilakukan uji asumsi klasik, yaitu:

\section{Uji Normalitas}

Menurut (Umar, 2014: 77) uji normalitas berguna untuk mengetahui apakah variabel dependen, independen atau keduanya berdistribusi normal, mendekati normal atau tidak.. Dasar pengambilan keputusan dari analisis probability plot, yakni: (1) jika data menyebar di sekitar garis diagonal dan mengikuti arah garis diagonal menunjukkan pola distribusi normal, maka model regresi memenuhi asumsi normal. (2) jika data menyebar jauh dari garis diagonal dan tidak mengikuti arah garis diagonal maka tidak menunjukkan pola distribusi normal, maka model regresi memenuhi asumsi normalitas.

\section{Uji Multikolinearitas}

Menurut Umar (2014: 80) uji multikolinearitas berguna untuk mengetahui apakah pada model regresi yang diajukan telah ditemukan korelasi kuat antar variabel independen. Untuk mengetahui apakah terjadi multikolinearitas dalam suatu model regresi dapat dilihat dari nilai VIF (variance inflation factor) dan nilai tolerance. Apabila nilai VIF $>10$ dan nilai tolerance $<0,01$ maka mengindikasikan terjadi multikolinearitas

\section{Uji Heteroskedasitas}

Menurut Umar (2014: 82) uji heteroskedasitas dilakukan untuk mengetahui apakah dalam sebuah model regresi, terjadi ketidaksamaan varians dari residual suatu pengamatan ke pengamatan lain.. Dasar uji heteroskedasitas yakni: (1) jika ada pola tertentu, yang teratur (bergelombang, melebar, kemudian menyempit), maka mengindikasikan telah terjadi heteroskedasitas, (2) jika ada titik-titik dibawah angka nol pada sumbu Y, maka mengindikasikan tidak terjadi heteroskedasitas.

\section{Uji Autokorelasi}

Menurut (2012: 178) uji autokorelasi bertujuan untuk menguji apakah dalam model regresi ada korelasi antara kesalahan pengganggu pada periode sebelumnya. Untuk memeriksa adanya korelasi, biasanya dilakukan uji statistic Durbin-Watson (DW) dengan langkah-langkah hipotesis sebagai berikut:

a. Jika DW terletak antara $d_{u}$ dan $\left(4-d_{u}\right)$ maka tidak ada autokorelasi 
b. Jika DW lebih kecil dari dl maka terdapat autokorelasi

c. Jika DW terletak antara $\left(4-\mathrm{d}_{\mathrm{u}}\right)$ dan $(4-\mathrm{dl})$ maka tidak ada kesimpulan yang pasti.

\section{Pengujian Hipotesis}

\section{Uji F}

Digunakan untuk menguji keberartian pengaruh dari seluruh variabel dependen secara bersama-sama terhadap variabel independen. Hipotesis ini dirumuskan sebagai berikut:

1. Rumusan hipotesis

Ho : Tidak ada pengaruh signifikan antara variabel $\mathrm{X}$ terhadap variabel $\mathrm{Y}$.

$\mathrm{Ha}$ : Ada pengaruh signifikan antara variabel $\mathrm{X}$ terhadap variabel $\mathrm{Y}$.

2. 2. Menghitung $F$ tabel (supardi,2013:233) menentukan nilai $F$ tabel didapat dari membaca tabel distribusi $\mathrm{F}$ untuk taraf signifikan (tertentu) dan df1 =n-k-1 dan $\mathrm{df} 2=\mathrm{k}-1$. Dalam hal ini $\mathrm{n}=$ banyak pasang data (sampel unit analisis) dan $\mathrm{k}=$ banyak variabel bebas.

\section{Koefisien Determinasi $\left(\mathbf{R}^{2}\right)$}

Koefisien determinasi pada intinya untuk mengukur seberapa jauh kemampuan model dalam menerangkan variabel dependen.

\section{HASIL DAN PEMBAHASAN}

Pengaruh Persediaan, Aktiva dan Modal Terhadap Laba Bersih Pada Sub Sektor Properti dan Real Estate yang Terdaftar di BEI Periode 2012-2016

\section{Analisis Regresi Berganda}

Pengelolaan data menggunakan software SPSS versi 20 dengan menggunakan data dari laporan keuangan perusahaan tahunan. Hasil pengelolaan tersebut dapat dilihat pada tabel berikut:

Tabel 2 Hasil Analisis Regresi Berganda

\begin{tabular}{|l|r|r|r|r|r|}
\hline \multirow{2}{*}{ Model } & \multicolumn{2}{|c|}{$\begin{array}{c}\text { Unstandardized } \\
\text { Coefficients }\end{array}$} & $\begin{array}{c}\text { Standardized } \\
\text { Coefficients }\end{array}$ & \multicolumn{1}{c|}{$\mathrm{t}$} & \multirow{2}{*}{ Sig. } \\
\cline { 2 - 4 } & \multicolumn{1}{|c|}{ B } & Std. Error & \multicolumn{1}{c|}{ Beta } & & \\
\hline (Constant) & -.103 & .813 & & -.126 & .900 \\
Persediaan & .156 & .157 & .180 & .994 & .326 \\
Aktiva & .748 & .349 & .660 & 2.144 & .038 \\
Modal & -.049 & .263 & -.047 & -.185 & .854 \\
\hline
\end{tabular}

a. Dependent Variable: LabaBersih

Dari hasil pengelolaan data maka didapatkan nilai-nilai koefisien seperti pada tabel diatas. Dari nilai-nilai koefisien tersebut didapatkan persamaan regresi linear sebagai berikut:

$$
\log Y=-0,103+0,156 X_{1}+0,748 X_{2}-0,049 X_{3}+e
$$

Pengaruh Total Persediaan, Total Aktiva dan Total Modal terhadap Laba Bersih pada Sub Sektor Properti dan Real Estate yang Terdaftar di Bursa Efek Indonesia 
Keterangan :

$\mathrm{Y}=$ Laba Bersih

$\mathrm{X}_{1}=$ Total Persediaan

$\mathrm{X}_{2}=$ Total Aktiva

$\mathrm{X}_{3}=$ Total Modal

Berdasarkan persamaan regresi linear berganda di atas dapat di interpretasikan sebagai berikut :

1. Nilai Konstan sebesar $-0,103$ memberikan arti bahwa apabila total persediaan $\left(\mathrm{X}_{1}\right)$, total aktiva $\left(\mathrm{X}_{2}\right)$ dan total modal $\left(\mathrm{X}_{3}\right)$ di asumsikan $=0$, maka laba bersih (Y) secara konstan bernilai $-0,103$.

2. Nilai Koefisien regresi variabel persediaan $\left(X_{1}\right)$ sebesar 0,156 memberikan arti bahwa total persediaan $\left(\mathrm{X}_{1}\right)$ berpengaruh positif terhadap laba bersih $(\mathrm{Y})$. Hal ini Menunjukkan jika total persediaan $\left(\mathrm{X}_{1}\right)$ meningkat sebesar $1 \%$, maka laba bersih akan meningkat sebesar 15,6\%.

3. Nilai Koefisien regresi variabel total aktiva $\left(X_{2}\right)$ sebesar 0,748 memberikan arti bahwa total aktiva $\left(\mathrm{X}_{2}\right)$ berpengaruh positif terhadap laba bersih. Hal ini menunjukkan jika total aktiva $\left(\mathrm{X}_{2}\right)$ meningkat sebesar $1 \%$, maka laba bersih akan naik sebesar $74,8 \%$.

4. Nilai Koefisien regresi variabel total modal $\left(\mathrm{X}_{3}\right)$ sebesar memberikan arti bahwa total modal $\left(\mathrm{X}_{3}\right)$ berpengaruh negatif terhadap laba bersih. Hal ini menunjukkan jika total modal $\left(\mathrm{X}_{3}\right)$ meningkat sebesar $1 \%$, maka laba bersih (Y) akan menurun sebesar $49 \%$.

\section{Uji Asumsi Klasik}

\section{Uji Normalitas}

Hasil uji normalitas dengan grafik histograf dan normal probability plot ditunjukkan sebagai berikut :

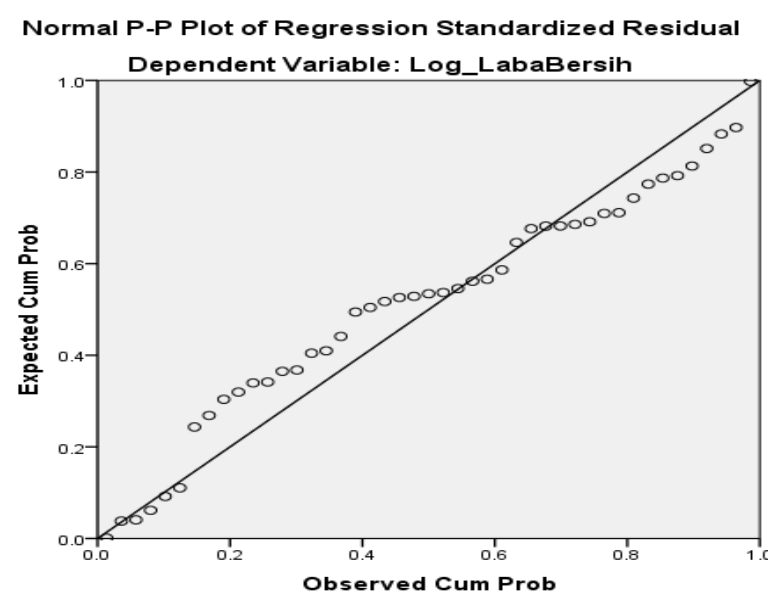

Gambar 1

Uji Normalitas

Dari Probability Plot di atas terlihat bahwa memperlihatkan titik menyebar di sekitar arah garis diagonal yang menunjukkan pola distribusi normal. 


\section{Uji Multikolinearitas}

\section{Tabel 3}

\section{Uji Multikolinearitas}

Coefficients $^{\mathrm{a}}$

\begin{tabular}{|l|r|r|r|r|}
\hline \multirow{2}{*}{ Model } & \multicolumn{2}{|c|}{$\begin{array}{c}\text { Unstandardized } \\
\text { Coefficients }\end{array}$} & \multicolumn{2}{c|}{ Collinearity Statistics } \\
\cline { 2 - 5 } & \multicolumn{1}{|c|}{ B } & Std. Error & Tolerance & \multicolumn{1}{c|}{ VIF } \\
\hline \multirow{2}{*}{ (Constant) } & -.103 & .813 & & \\
\\
1 & .156 & .157 & .299 & 3.347 \\
Log_Persediaan & .748 & .349 & .103 & 9.678 \\
Log_Aktiva & -.049 & .263 & .152 & 6.583 \\
Log_Modal &
\end{tabular}

a. Dependent Variable: Log_LabaBersih

Dari hasil peneitian pada tabel 4.3. terlihat bahwa nilai Tolerance dan VIF menunjukkan bahwa tidak ada satu variabel independen yang memiliki nili VIF lebih besar dari 10 dan tidak ada satu nilai Tolerance variabel independen yang memenuhi nilai tolerance yaitu kurang dari 0,1 .

\section{Uji Heteroskedasitas}

Hasil uji heteroskodasitas dapat dilihat pada grafik scatterplot berikut ini:

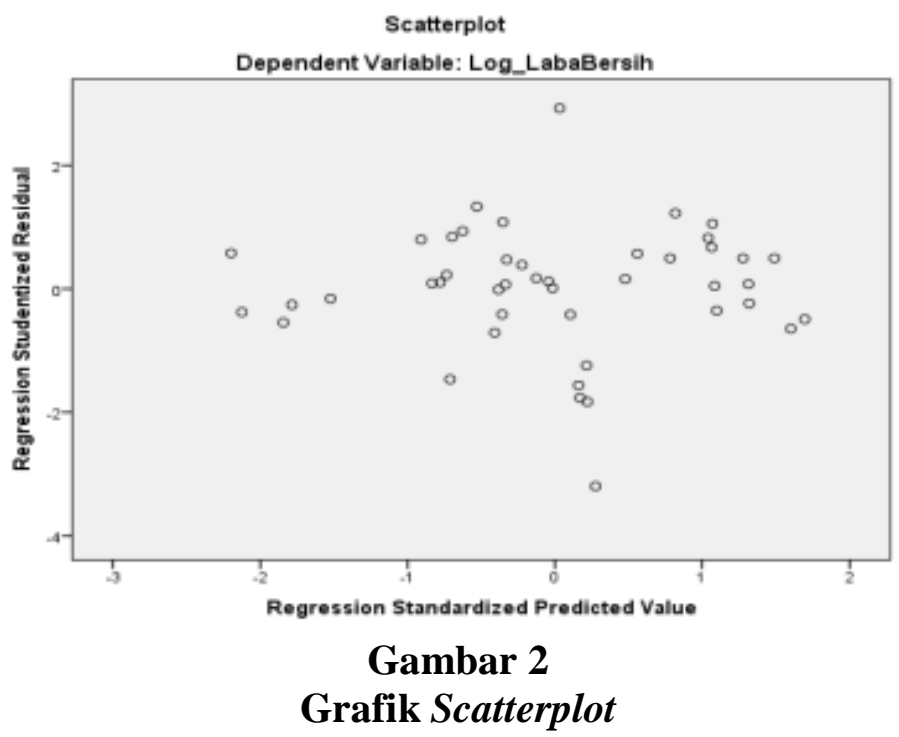

Dari grafik scatterplot tersebut dapat kita lihat bahwa titik-titik menyebar secara acak serta tidak membentuk pola tertentu atau tidak teratur. Hal ini mengindikasikan tidak terjadinya heteroskedasitas pada model regresi sehingga model ini layak di pakai.

Pengaruh Total Persediaan, Total Aktiva dan Total Modal terhadap Laba Bersih pada Sub Sektor Properti dan Real Estate yang Terdaftar di Bursa Efek Indonesia 


\section{Uji Autokorelasi}

Tabel 4.

Model Summary

\begin{tabular}{|l|r|r|r|r|}
\hline Model & \multicolumn{1}{|c|}{$\mathrm{R}$} & R Square & Adjusted R Square & \multicolumn{1}{c|}{ Durbin-Watson } \\
\cline { 5 - 5 } & & & & \\
\hline 1 & $.774^{\mathrm{a}}$ & .599 & .569 & 1.161 \\
\hline
\end{tabular}

a. Predictors: (Constant), Modal, Persediaan, Aktiva

b. Dependent Variable: LabaBersih

Berdasarkan hasil perhitungan analisis data dengan menggunakan SPSS versi 20 diperoleh hasil uji autokorelasi seperti tabel 4.3. dari tabel tersebut dapat dilihat angka Durbin-Watson Test sebesar 1.161. Karena angka D-W test 1.161 terletak dibawah +2 , maka diambil keputusan bahwa model regresi ini ada autokorelasi positif. Sehingga dapat dilakukan model regresi dalam peneltian ini layak untuk memprediksi besarnya laba bersih.

\section{Uji Hipotesis}

\section{Uji F}

Uji statistik F pada dasarnya menunjukkan apakah semua variabel independen yang dimasukkan dalam model mempunyai pengaruh secara bersamasama/ simultan terhadap variabel dependen. Pengujian hipotesis pertama: total persediaan, total aktiva dan total modal terhadap laba bersih pada sub sektor properti dan real estate yang terdaftar di BEI periode 2012-2016. Berikut ini hasil Uji F yang diolah menggunakan SPSS 20 disajikan dalam tabel berikut ini :

Tabel 5

ANOVA $^{\mathrm{a}}$

\begin{tabular}{|l|r|r|r|c|c|}
\hline Model & Sum of Squares & df & $\begin{array}{c}\text { Mean } \\
\text { Square }\end{array}$ & F & Sig. \\
\hline Regression & 6.609 & 3 & 2.203 & 20.377 & $.000^{\mathrm{b}}$ \\
1 Residual & 4.433 & 41 & .108 & & \\
Total & 11.042 & 44 & & & \\
\hline
\end{tabular}

a. Dependent Variable: LabaBersih

b. Predictors: (Constant), Modal, Persediaan, Aktiva

Kriteria pengujian secara simultan (Uji F) dengan membandingkan $\mathrm{F}$ hitung dengan $F$ tabel pada taraf signifikan $\alpha=0,05$. Adapun kriteria keputusan pada pengujian ini adalah Jika $F_{\text {hitung }}>F_{\text {tabel }}$ artinya Ho ditolak dan Ha diterima artinya terdapat pengaruh signifikan antara variabel $\mathrm{X}$ terhadap variabel $\mathrm{Y}$. Jika $F_{\text {hitung }}<$ $\mathrm{F}_{\text {tabel }}$ artinya Ho diterima dan $\mathrm{Ha}$ ditolak artinya tidak terdapat pengaruh signifikan antara variabel $\mathrm{X}$ terhadap variabel $\mathrm{Y}$. Dengan demikian $\mathrm{F}$ hitung sebesar $20.377>\mathrm{F}_{\text {tabel }}$ sebesar 3,07 artinya total persediaan, total aktiva dan total modal terdapat pengaruh signifikan terhadap laba bersih pada sub sektor properti dan real estate yang terdaftar di BEI periode 2012-2016.

Pengaruh Total Persediaan, Total Aktiva dan Total Modal terhadap Laba Bersih pada Sub Sektor Properti dan Real Estate yang Terdaftar di Bursa Efek Indonesia 


\section{Koefisien Determinasi}

Hasil perhitungan SPSS untuk melihat korelasi dan determinasi dapat dilihat pada model summary berikut ini:

Tabel 6

Model Summary ${ }^{b}$

\begin{tabular}{|l|r|r|r|r|}
\hline Model & \multicolumn{1}{|c|}{$\mathrm{R}$} & R Square & Adjusted R Square & \multicolumn{1}{|c|}{ Durbin-Watson } \\
\cline { 5 - 5 } & & & & \\
\hline 1 & $.774^{\mathrm{a}}$ & .599 & .569 & 1.161 \\
\hline
\end{tabular}

a. Predictors: (Constant), Modal, Persediaan, Aktiva

b. Dependent Variable: LabaBersih

Koefisien korelasi antara total persediaan, total aktiva dan total modal kerja terhadap laba bersih pada sub sektor properti dan real estate yang terdaftar di BEI periode 2012-2016 adalah 0,774, artinya terdapat hubungan yang erat antara variabel total persediaan, total aktiva dan total modal terhadap laba bersih pada sub sektor properti dan real estate yang terdaftar di BEI periode 2012-2016.

Dari hasil pengujian korelasi maka diperoleh nilai R Square sebesar 0,599 angka ini menyatakan bahwa variabel total persediaan, total aktiva dan total modal terhadap laba bersih pada sub sektor properti dan real estate yang terdaftar di BEI periode 2012-2016 sebesar 59,9\% sebaliknya 40,1\% disebabkan oleh variabel lain diluar variabel yang diteliti.

\section{Pembahasan}

Berdasarkan hasil analisis regresi yang dilakukan dalam penelitian ini, maka dapat dijelaskan hal-hal berikut ini:

Secara simultan total persediaan, total aktiva dan total modal pada sub sektor properti yang terdaftar di BEI periode 2012-2016. Hal ini ditunjukkan dengan $F_{\text {hitung }}$ yang lebih besar dari $F_{\text {tabel }}(20.377>3,07)$ dan dengan membandingkan besarnya taraf signifikan sebesar 0,05 maka $0,000<0,05$ berarti dapat dikatakan bahwa ada pengaruh positif antara variabel total persediaan, total aktiva dan totall modal kerja terhadap laba bersih pada sub sektor properti dan real estate yang terdaftar di BEI periode 2012-2016. Hasil ini menunjukkan bahwa informasi mengenai laba bersih tidak dapat diprediksi dengan cara mengukur total persediaan, total aktiva dan total modal terhadap laba bersih pada sub sektor properti dan real estate yang terdaftar di BEI periode 2012-2016.

Selanjutnya pengujian secara parsial menyatakan bahwa total persediaan tidak memiliki pengaruh secara signifikan terhadap laba bersih pada sub sektor properti dan real estate yang terdaftar di BEI periode 2012-2016 karena $t$ hitung lebih kecil dari $t$ tabel $(0,994<2.07961)$ koefisien regresi total persediaan sebesar 0,156 memberikan arti positif terhadap laba bersih. ini menunjukkan bahwa total persediaan mempunyai hubungan yang searah dengan laba bersih. Hal ini mengandung arti bahwa setiap kenaikan total persediaan satu satuan maka laba bersih akan meningkat sebesar 15,6\%.

Pengujian secara parsial menyatakan bahwa total aktiva memiliki pengaruh terhadap laba bersih pada sub sektor properti yang terdaftar di BEI periode 2012-2016 karena $t$ hitng lebih besar dari $t$ tabel $(2.144>2.07961)$ koefisien regresi sebesar 0,748 memberikan arti bahwa total aktiva berpengaruh positif

Pengaruh Total Persediaan, Total Aktiva dan Total Modal terhadap Laba Bersih pada Sub Sektor Properti dan Real Estate yang Terdaftar di Bursa Efek Indonesia 
terhadap laba bersih. Hal ini menunjukkan bahwa dengan penambahan total aktiva sebesar $1 \%$ maka akan meningkatkan laba bersih sebesar 74,8\%.

Pengujian secara parsial menyatakan bahwa total modal tidak memiliki pengaruh yang signifikan terhadap laba bersih pada sub sektor properti dan real estate yang terdaftar di BEI periode 2012-2016 karena $\mathrm{t}$ hitung $<\mathrm{t}$ tabel $(-0,185<$ 2.07961) koefisien regresi sebesar $-0,049$ memberikan arti bahwa total modal berpengaruh positif terhadap laba bersih. hal ini menunjukkan bahwa penambahan total modal sebesar $1 \%$ akan menurunkan laba bersih sebesar $49 \%$.

Nilai koefisien determinasi ( $R$ Square) sebesar 0,599, hal ini berarti total persediaan, total aktiva dan total modal mampu menjelaskan laba bersih sebesar $59,9 \%$ dipengaruhi oleh faktor lain diluar penelitian ini.

\section{SIMPULAN}

Berdasarkan hasil pembahasan yang dilakukan pada bab sebelumnya, maka dapat dirumuskan beberapa kesimpulan sebagai berikut:

1. Berdasarkan hasil pengujian secara simultan (uji F) dapat diketahui bahwa variabel total persediaan, total aktiva dan total modal berpengaruh positif dan signifikan terhadap laba bersih, hal ini dibuktikan oleh nilai $F_{\text {hitung }}$ yang lebih besar dari $\mathrm{F}_{\text {tabel }}(20.377>3,07)$

2. Berdasarkan hasil pengujian secara parsial (uji t) dapat diketahui bahwa terdapat pengaruh positif yang tidak signifikan antara variabel total persediaan terhadap laba bersih. Variabel total aktiva berpengaruh positif yang signifkan terhadap laba bersih. Variabel total modal berpengaruh negatif tidak signifikan terhadap laba bersih.

\section{DAFTAR PUSTAKA}

Adisetiawan, R., dan Surono, Yunan., 2016, Earning Management and Accounting Information Value: Impact and Relevance, Business, Managemen and Economics Research, 2(10): 170-179

Adisetiawan, R., dan Ahmadi, 2016, The Impact of Earning Management Against Market Reaction: Empirical Evidance from Indonesia, International Research Journal of Finance and Economics, 146, 112-128

Algifari, (2015). Analisis Regresi.Edisi kedua.BPFE : Yogyakarta.

Belkaoui, Ahmed (2006). Teori Akuntansi, Diterjemahkan Oleh Marwata dkk. Salemba Empat: Jakarta

Budi, Rahardjo. (2001). Akuntansi dan Keuangan Untuk Manajer Non Keuangan. Graha Ilmu : Yogyakarta

Effendi, Usman.(2014). Asas Manajemen. PT. Rajagrafindo Persada : Jakarta. Fahmi, Irham .(2014). Pengantar Manajemen Keuangan.Alfabeta : Bandung. Hanafi, Mahmud M. Dan Abdul Halim. (2007). Analisa Laporan Keuangan. UUP YKPN : Yogyakarta.

Hartono, Jogiyanto. (2009). Teori Portofolio dan Analisis Investasi. Salemba Empat: Yogyakarta

Hery, (2015).Analisis Laporan Keuangan Pendekatan Ratio Keuangan. Edisi Pertama, Jakarta (2012). Analisis Laporan Keuangan. Raja Grafindo Persada, Jakarta

Munawir, S. (2007).Analisa Laporan Keuangan. Edisi Keempat. Cetakan Ketiga Belas.Liberty : Yogyakarta.

Pengaruh Total Persediaan, Total Aktiva dan Total Modal terhadap Laba Bersih pada Sub Sektor Properti dan Real Estate yang Terdaftar di Bursa Efek Indonesia 
Riyanto, Bambang. (2001). Dasar-dasar Pembelanjaan Perusahaan, BPFE: Yogyakarta

Salvatore, (2006). Managerial Economics in a Global Economy 4 Edition, Harcourt College Publishers

Sugiyono, (2012), Metode Penelitian Kantitatif, Kualitatif dan R\&D, Alfabeta Bandung

Sutrisno, (2008).Manajemen Keuangan Teori dan Aplikasi. BPFE : Yogyakarta

Suad, Husnan. (2001). Dasar-dasar Teori Portofolio dan Analisis Sekuritas, Yogyakarta

Tandelilin, Edaurdus. (2010). Manajemen Investasi dan Portofolio. Edisi Pertama, Kanisius : Yogyakarta

Tunggal, Amin Widjaja. (2009). Intisari Akuntansi. Yudistira: Jakarta.

Umar, Husein. (2013). Desain Penelitian. PT. RajaGrafindo: Jakarta

Adisetiawan, R., dan Atikah, 2018, Does Stock Split Influence to Liquidity and Stock Return?, (Empirical Evidence in The Indonesian Capital Market), Asian Economic and Financial Review, 8(5): 682-690

Pengaruh Total Persediaan, Total Aktiva dan Total Modal terhadap Laba Bersih pada Sub Sektor Properti dan Real Estate yang Terdaftar di Bursa Efek Indonesia 